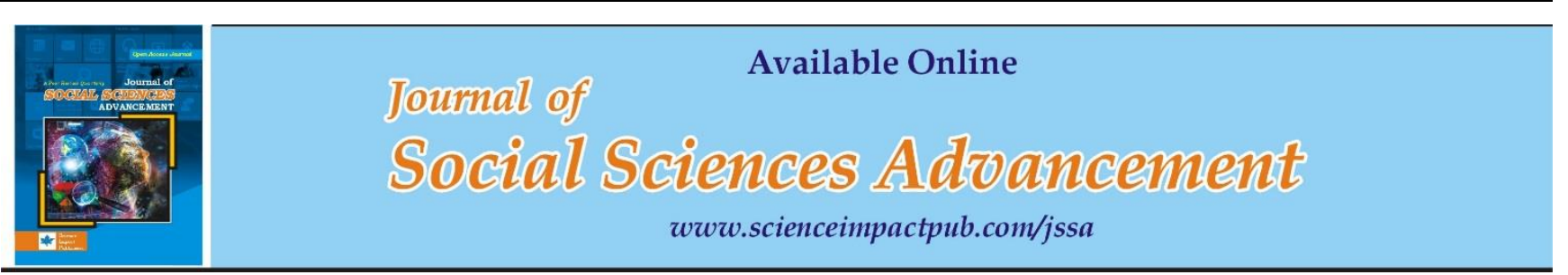

\title{
USING GAMES TO IMPROVE LEARNING VOCABULARY FOR NON-ENGLISH-MAJORED STUDENTS AT BAC LIEU UNIVERSITY
}

\author{
Dao Thi Anh Nguyen ${ }^{1}$ \\ ${ }^{1}$ Faculty of Education, Bac Lieu University, Viet Nam
}

\begin{abstract}
The fact is that teaching and learning vocabulary is one of the most complicated problems, and the traditional way of vocabulary instructions proves ineffective, and even worse, decreasing students' interest and motivations in their study and work. An experimental case study was conducted with two respective classes at Bac Lieu University, Vietnam. Accordingly, in one experimental class, vocabulary was taught with the cooperative vocabulary games at the practice and revision stages. The results revealed that games could be used to improve non-English-majored students' learning vocabulary at Bac Lieu University because of its following major effects. Firstly, games brought in relaxation and fun for students, thus helped them learn and retain new words more easily. In other words, students could be more interested in learning the vocabulary. Secondly, games usually involved friendly competition and they kept learners interested. These created the motivation for learners of English to get involved and participated actively in the learning activities. Finally, games created meaningful contexts for language practice. The more they practiced the more they could use the words. Then they learnt better and had higher results in their achievement as well.
\end{abstract}

Keywords: Learning vocabulary; Games; Motivation; Interest; Practice

Corresponding Author: Dao Thi Anh Nguyen, Email: ntadao@blu.edu.vn

(C) The Author(s) 2020.

\section{INTRODUCTION}

\section{Background of the study}

Together with Vietnam's open - door policy came into existence in 1986, English has been remerging as the most important foreign language after the domination of Russian for many years. Especially, the fact that Vietnam becomes the $150^{\text {th }}$ member of the biggest business organization in the world, WTO (World Trade Organization), following the trend of globalization in early 2007 further justifies that English is now the dominant foreign language in Vietnam. In addition, English is also a compulsory subject for graduation in Vietnamese university education systems. Therefore, learning English seems necessary in the students' life.

Bac Lieu University (BLU) is a multidisciplinary higher education institution in Bac Lieu Province, a cultural, scientific, and educational hub in the region and the Mekong Delta as well. Since its inception of 2006, Bac Lieu University serves the increasing demand for high quality human resources of the province. However, most of the students come from the remote areas of the province and other regions, they do not have adequate English vocabulary or proficiency when communicating with others. Further, due to a lot of subjective and objective reasons, teaching and learning vocabulary in Bac Lieu University become a burden to both teachers and students. Another important thing is that the teachers strictly follow the textbook because of time limitations. Thus, teaching and learning English in general and learning vocabulary have a lot of difficulties in particular.

Furthermore, teachers tend to give a long list of isolated words and their meanings, and students are required to learn all new words by heart or to learn them passively through the teacher's explanation. It can be said that the implicit purpose of teaching vocabulary by most teachers at Bac Lieu University is to help students master as many words as possible. Using words learned in real communication is often ignored. With the limited time stipulated in the syllables, the time in class for most teachers is the time for providing new vocabulary and patterns through the reading texts. Knowing a word to most students is to know the meaning of the word and nothing else. Teaching vocabulary, therefore, is not fulfiller. In the current learning situation, it can save time for both teachers and students. The most serious problem, however, is that such a way of teaching vocabulary might kill students' interests and involvement in their language learning process.

From these above practical reasons, it is necessary to apply appropriate techniques to enhance students' vocabulary learning process and to help them get good results in their examination. Consequently, the situation urges the researcher to conduct the study about the effect of games on learning vocabulary. The researcher has applied games 
in order to add the variety to vocabulary lessons and to enable students to practice formally learned language in a more stimulating approach.

\section{Significance of the study}

The results of this study may offer a new insight into games as a practical and effective teaching device so that teachers of English can prepare students a good stock of vocabulary to be self-confident to communicate and to take any examinations in the term.

In addition, with using games for learning vocabulary, the researcher hopes to create a relaxing and enjoyable atmosphere in classrooms. This decreases the students' indifference and enhancing good mood and positive attitude towards language learning.

And then, playing games also creates communication contexts, which fosters memory and recalls. Furthermore, with respect to the social and emotional aspects, playing games builds up better cooperation among group students, thereby improving their positive participation in classroom context. Thus, using of games is a powerful way to help individuals learn to deal with their social issues through interactions and negotiation.

Finally, this study is also to share understanding and experience about an effective technique of learning vocabulary with colleagues who want to bequeath the next generations the joy of discovering and enjoying the beauty and richness of language.

\section{Research questions}

On the premise of the literature and research, the author wants to discover the aspects that make games a powerful teaching tool in improving students' learning vocabulary. In the light of this primary purpose, the only research question is "How do games affect Bac Lieu University non-English-majored students in their learning vocabulary?"

\section{GAMES IN ENGLISH VOCABULARY LEARNING}

It can be understood that with respect to the process of second language acquisition (SLA), i.e., English, the learners are required to learn vocabulary, grammar, and language skills and so on to be competent in that specific language (Ellis, 1997; McCarthy, 1992; Nunan, 1999). Accordingly, one of the key factors in learning a foreign language is vocabulary because it plays an important role in language competence (McCarthy, 1992). Simply put, the fact that a language speaker can be considered competent or not depends much on their ability of using the vocabulary (Harmer, 1993; Nunan, 1999).

In other words, as one of the pillars of language learning vocabulary is an essential tool deciding the success in communication (Chou, 2012). Thanks to that, learners can express their opinions and even leverage their rich vocabulary to link four language skills, namely listening, speaking, reading, and writing (Dehghanzadeh et al., 2019; Thornbury, 2004). Ultimately, vocabulary is considered the foundation to develop other language skills (McCarthy, 1992; Thornbury, 2004). Firstly, learners with a wide range of practical vocabulary (i.e., with large vocabulary and precise knowledge about words) can get the information more easily when listening to diverse sources (Harmer, 1993). Secondly, vocabulary plays an important role in reading. It is clear that a large vocabulary stock can help learners understand the contents quickly. Besides, vocabulary is also very necessary for productive skills (i.e., expressing their thoughts fluently in daily conversations and writing effectively) (Nunan, 1999). Therefore, how easily and confidently a learner can express himself or herself depends much on their vocabulary.

Yet, regarding English language learning, learners typically argue that learning and remembering English vocabulary along with their correct form or usage are tedious learning activities (Bahari, 2020; Hwang \& Wang, 2016). Prior empirical studies disclose several factors, namely anxiety, motivation, attitude, and abilities, could greatly affect English vocabulary learning processes and outcomes (Ebrahimzadeh \& Alavi, 2016). Thus, attention to use of games has certainly grown as one of the most enjoyable and effective instructional method for student motivation and engagement in English learning (Bahari, 2020; Ebrahimzadeh \& Alavi, 2016; Zou et al., 2019).

Extant review pertaining to game-based vocabulary learning literature reveals that games facilitate language vocabulary acquisition for several reasons: (1) improving student intrinsic motivation, (2) containing rich textual input for meaningful language engagement, and (3) reducing student language learning anxiety (Obee, 1999; Rison, 1994; Romp, 1997; Yip \& Kwan, 2006). Accordingly, games exert considerably positive impacts on English vocabulary learning and teaching by contextualizing the process of vocabulary learning and creating a motivating learning environment (Hwang \& Wang, 2016). Further, game-based instructions when enhancing learners' motivation and engagement probably provide them with further confidence and freedom during their vocabulary learning (Chen \& Yang, 2013; Ebrahimzadeh \& Alavi, 2016). Ultimately, language-rich games enhance both emotional and cognitive developments through doing, thinking, and playing, offering students with opportunities to increase their vocabulary size (Bahari, 2020; Dehghanzadeh et al., 2019). 


\section{RESEARCH DESIGN AND METHODOLOGY \\ Research design}

This is a multitude of methods to carry out a research. However, it's the researcher's duty to choose which method is the most appropriate, this choice is generally imposed by the nature of the study itself and the researcher's objects. Thus, this is an experiment to invest the effectiveness of using games in improving non-English-majored students' learning vocabulary.

\section{1) Sampling}

While not the best sampling procedure for representativeness, the common form of sampling in education research is non-probability sampling. For this project, the target population was non-English-majored students at Bac Lieu University. The subjects were chosen according to the non-probability sampling, also called convenience or available sampling (Creswell, 2012). They were the two classes that the researcher was assigned to teach.

At the time of data collection, the target population of the study was 580 non-English-majored freshmen in Bac Lieu University in eight classes with various majors such as accounting, aquiculture, information technology, nursery education, and primary education. They all belong to the three-year bachelor programs. The students in these two classes are further described in Section 3.1.2.

\section{2) Participants}

Due to the tremendous population of students, the researcher could not study the whole population. The one hundred twenty participants in this research were drawn from the population of 580 non-English-majored freshmen in Bac Lieu University. For a population of this size, according to a guidance table develop by Bartlett et al. (2001), a sample from 60 to 120 non-English-majored students was satisfied. Thus 60 students from class 5CĐKT1 and 60 students from class 5 CĐKT2 were involved in the study. The criteria for choosing these two classes among the eight classes of the three-year bachelor programs were that they had the same majors (both majored in accounting).

\section{The experiment}

To investigate the effects of using games on non-English-majored students' learning vocabulary at Bac Lieu University to know whether games could be used to improve their vocabulary learning, the researcher carried out the experiment. In order to prepare for the experiment, all vocabulary exercises in the students' book were redesigned as games. During eight weeks, the vocabulary in English KnowHow 1 written by Naber and Blackwell (2005) was practiced and reviewed differently in these two classes. Accordingly, class 5CĐKT 1 was chosen randomly as the control group, and class 5CĐKT2 assigned as the experiment group. The study started at the beginning of the second semester of school year 2020 and lasted two months (from January to March, 2020) with the aim of discovering manifestations of students' learning vocabulary under the treatment of games. There were eight units for students to study in the second semester, Unit 9 to Unit 16.

During the experiment, the teacher taught one unit per week in two periods, each lasted forty-five minutes. Meanwhile, the teacher spent about 20 minutes on teaching vocabulary. In fact, the class 5CĐKT 1 was taught and reviewed vocabularies in a normal process as it had been done in the first semester. The teacher presented new vocabularies with real objects, pictures, mining, definitions, synonyms, antonyms, and so on. After the presentations, the students did the drill practices and the vocabulary exercises in their workbooks.

In the class 5CĐKT 2, however, the teacher helped students practice and reviewed new vocabularies with the language games. After 4 and 8 weeks, students took the tests on vocabulary. To be specific, 5CĐKT2 was taught with the same way in the presentation of the new vocabulary as that of the control class. Then, a variety of games including guessing, matching, and searching via activities were presented in the practice and revision stage of teaching vocabulary.

\section{Data collection instruments}

As discussed above, using games can make students feel relaxed in studying motivation and better chance of practicing in the studying vocabulary (Chen \& Yang, 2013; Lee, 1997). Consequently, they achieve higher scores.

In order to collect data for variables related to relaxation atmosphere in the class, interest, motivation and better chance of practicing, the researcher used the questionnaires. To investigate the improvement in vocabulary learning of the students during the experiment, the researcher used the test.

In the experiment, games were used in the practice and revision stage for 20 minutes on teaching vocabulary. Using these activities was to increase students' practice of the new vocabulary, thus helped them remember new words easily. In other words, it would develop students' vocabulary competence. In addition, to play games students had to rely on themselves and cooperate among themselves. It was the principle of self-reliance, cooperation, and joint learning that awaked and maintained students' interest in the lesson. As interest is a main ingredient of motivation, it could be conducted that games contributed much to provide motivation to students. Once students were highly motivated, they would likely concentrate on studying and study better and they were assumed to get greater results. 


\section{Questionnaires}

According to Creswell (2012), questionnaire is a survey instrument comprising a series of questions and/or attitude and opinion statements designed to obtain responses, which can be converted into measures of the variable for statistical analysis. This type of data collection method was chosen for its advantage. That could be the less timeconsuming in gathering as well as processing data from a potentially large number of respondents. On the contrary, one of the disadvantages of questionnaire was the low response rate thus poor feedback. In order to minimize this problem, the researcher personally came to the class to directly deliver and explain the instruction the students. The data was then collected immediately upon completion.

There were two parts in the questionnaire adapted from Ur (2009): (1) items relating to the participants' background and (2) feedback on learning vocabulary including students' evaluation of the effects of learning vocabulary with games. The information collected in the first section of the survey was the students' age, gender, and time to study English.

In the second part of the questionnaire, there were six questions. Questions 1 and 2 were set of preferable degree with four scales, i.e., very much, much, not much, and not at all. Question 1 wanted to know the students' attitude towards learning English. Such an understanding was necessary for the researcher to give recommendations about applying games in teaching later. The respondents were required to answer the question according to their degree of agreement.

Question 2 asked students whether they like learning vocabulary with games. Basing on the answer of questions 2 , students continued whether with Question 3 or Question 4. If they chose very much or much, they would work with question 3 and if they chose not much or not at all they would answer question 4.

Question 3 provided the reasons in relation to the effects of teaching vocabulary with games on learners such as games provided relaxation, motivation, interest, and better chance for practice.

Question 4 supplied the reasons why students might not feel interested in learning with games. Question 5 offered five suggestions about how to organize and apply games to improve students' learning vocabulary and the last question asking about how often games should be applied. With Questions 3, 4 and 5 students were asked to provide extra explanations if the options provided did not much their feedback or further feedback on the reasons mentioned above. Question 6 asked about the suitable frequency to apply games in vocabulary class.

\section{Administering the questionnaires}

The questionnaire was designed in a closed format to avoid the difficulties in tabulating and analyzing statistically. To have further explanation, open space was also provided with Questions 3, 4, and 5 for students to provide other reasons not mentioned in the questionnaire or their comments of the reason why. Besides, it was written in English but the distributed papers were translated into Vietnamese to avoid participants' misunderstanding and to collect precise information. At the end of the experiment, the researcher gave the questionnaire to students of the experiment class, explained the objectives of the study and asked students to fill the questionnaires in class. She also answered all the difficulties arisen when students answered the questions and collected the questionnaire afterward.

\section{Tests}

There were two tests on vocabulary in the experiment. The two classes took the first test (mid-term test) after learning 4 units (i.e., Units 9-12 of the second semester). The test was to assess the vocabulary which they had learned from the prior units. The second test (final test) was given to students of two classes at the end of the course. Both tests had matching and multiple-choice questions and they had the same format. The second test was focused on the words learned in last four units (i.e., Units 13-16). To be specific, each test was within fifteen minutes. Each of these tests was taken by the students' right before the class was finished. The two tests were done without any prior notice. Finally, the students' marks were carefully recorded and analyzed, based on three criteria 'strong' (from 7 to 10), 'average' (5 and 6), and 'weak' (from 1 to 4).

In general, this paper has just presented main points of the research methodology. It includes the research site, participants, and instruments for data collection. Based on this, the text part will analyze and discuss data collected from the two tests and questionnaire and then withdraw findings from the figures that had just been calculated.

\section{RESULTS AND DATA ANALYSIS}

\section{Data analysis methodology}

In this session, the students' responses to the questionnaires were analyzed, and the differences of experiment and control groups were also compared via the results of the mid-term test and final test scores. All of these analyses were aimed at discovering 'How do games affect Bac Lieu University non-English-majored students in their learning vocabulary?' 
Responses from the questionnaire were analyzed both qualitatively and quantitatively. Percentage and frequency of the first five questions were calculated and presented inhabits and graphs. The open answers after questions 3, 4, 5 involved qualitative statistic. Their ideas, thoughts and emotions were discussed according to groups of the themes. The results of the tests gained from both groups were divided into three sub-groups: the strong, average and weak one. The mean of scores was also calculated based on the SPSS of version 16 to support the discussion.

\section{Questionnaires}

In term of students' age, the range of age between the experimental group and the control group is from 19 to 21 with the age mean is 20 , i.e., most of the students were young. One of the two classes was designed randomly as an experiment group. This class, which had 60 members, was more heavily weighted towards males (32) than females (28). Similarly, the other was treated as the control group also having 60 students, 39 of whom were females and 21 were males. Most of students' time for studying English was not the same. In fact, some of them had studied English for 4 years while other students had spent 8 years due to their different living condition. Consequently, these factors showed that they were good enough to understand games which were applied to teach vocabulary effectively.

\section{1) Question 1}

As in Table 1, up to $16,7 \%$ of students liked learning English vocabulary very much because they realized the importance of vocabulary in the language development. In addition, vocabulary was part of the school examination and necessary for their future studies. There were 53,3\% of students who answered that they liked learning English vocabulary because of their better vocabulary stock. $26,7 \%$ of students said that they were not much interested in vocabulary and $3,3 \%$ of students did not like learning vocabulary at all.

Table 1: Students like learning English vocabulary

\begin{tabular}{lrr}
\hline Do you like learning English vocabulary? & Participants & Percentage (\%) \\
\hline Very much & 10 & $16,7 \%$ \\
Much & 32 & $53,3 \%$ \\
Not much & 16 & $26,7 \%$ \\
Not at all & 2 & $3,3 \%$ \\
\hline
\end{tabular}

Results led to the fact that students were always interested in learning English vocabulary. Up to $70 \%$ of students showed that they concerned much about learning English vocabulary because it would help them improve their communication.

\section{2) Question 2}

When the experiment students were asked whether they liked learning vocabulary with games, $21.7 \%$ of students said that they liked it very much. Likewise, 58.3\% students claimed that they liked learning with games much. Yet, $16.7 \%$ of students would not like this way of learning vocabulary much. Only $3.3 \%$ of students would not like learning with games at all (see Table 2). To conclude, the students' interest in learning vocabulary with games was noticeable. Clearly, playing games helped students express their thoughts confidently. Accordingly, they had chanced to practice what they had leant before. It is one of the useful ways to improve their communicative ability.

Table 2: Students like learning English vocabulary with games

\begin{tabular}{lrr}
\hline Do you like learning vocabulary with games? & Participants & Percentage (\%) \\
\hline Very much & 13 & $21.7 \%$ \\
Much & 35 & $58.3 \%$ \\
Not much & 10 & $16.7 \%$ \\
Not at all & 2 & $3.3 \%$ \\
\hline
\end{tabular}

\section{3) Question 3}

This question located six main reasons for learning vocabulary with games. All were concerned with usefulness of using games. As presented in Table 3, the total number of 48 students preferring this approach in Question 2 had to provide the reasons for their favor. The largest group, $20 \%$ said that they liked studying vocabulary with games as they could use the newly learned vocabulary in real situation. The group standing second in proportion (18.4\%) said that they could practice using the newly learned vocabulary in many ways. Thus, games created meaningful contexts for language practice. The more they practiced the more they could use the words. Then they learnt better and had better results in their study.

Further, $13.3 \%$ confessed that they felt comfortable learning with games. $10 \%$ stated that they could remember vocabulary easily, $10 \%$ explained that they felt motivated, and the smallest said that they like learning vocabulary with games because the lessons were interesting in giving the opinions about the effects of games, students' responses to this question were mainly focused on the themes: relaxation, motivation, and meaningful contexts for language practice.

As discussed in extant literature, games have showed to have more advantages and effectiveness in learning vocabulary in various ways. First, games could bring students about interest and relaxation. Thus, games helped them 
learn and retain new words more easily. In fact, with respect to qualitative findings, five students wrote these comments: 'I like to learn English vocabulary with games that way because I feel comfortable and funny when playing games with my peers'. Students expressed their thoughts using the expressions as 'Pleasant environment', 'Helpful peers', 'I like the cooperation in vocabulary class', and 'My teacher was friendly and enthusiastic'. Games usually involved friendly and healthy competition and they keep learners interested in the activities.

Table 3: Students' reasons why they like learning vocabulary with games

\begin{tabular}{lrr}
\hline You like learning vocabulary with games because.... & Frequency & Percentage (\%) \\
\hline I am comfortable in the classroom & 8 & $13.3 \%$ \\
The lessons are interesting & 5 & $8.3 \%$ \\
I can practice using the newly learned vocabulary in many ways & 11 & $18.4 \%$ \\
I can use the newly learned vocabulary in real situation & 12 & $20 \%$ \\
I can remember vocabulary easily & 6 & $10 \%$ \\
I feel motivated & 6 & $10 \%$ \\
\hline
\end{tabular}

$$
N=60
$$

\section{4) Question 4}

As in Table 4, Question 4 aimed to understand further the reasons of students' games unfavor. Totally there were 12 students $(20 \%)$ from the whole class showed their unfavorable feeling to some extent towards learning with games. $16.7 \%$ of them did not like study vocabulary much while $3.3 \%$ did not like it at all.

Table 4: Students' unfavorable reasons in learning vocabulary with games

\begin{tabular}{lrr}
\hline You do not like learning vocabulary with games because .... & Frequency & Percentage \\
\hline You feel uncomfortable playing games in the classroom & 2 & $3.3 \%$ \\
It is easy to make noise & 3 & $5 \%$ \\
It is a time consuming & 3 & $5 \%$ \\
It does not help much in learning vocabulary & 4 & $6.7 \%$ \\
\hline
\end{tabular}

\section{5) Question 5}

To investigate students' ideas about how to help them learn vocabulary with games effectively, Question 5 was proposed. Students' answers were presented in Table 5. The largest group (26.7\%) suggested that teachers should choose the suitable games to the contents of the lesson, and $25 \%$ of students asked teachers to explain the rules clearly before playing. Further, $18.3 \%$ of students asked that the teachers brought them more chances to practice speaking English and 16.7\% asked teachers to combine between games with the music and pictures to enhance the effects. Only $13.3 \%$ of students required that teachers should give the gift or marks, for example, for the winners.

Table 5: Students' suggestion to teach vocabulary with games effectively

\begin{tabular}{lcc}
\hline $\begin{array}{l}\text { According to you, to help you learn vocabulary with games } \\
\text { effectively, the teacher should... }\end{array}$ & Frequency & Percentage \\
\hline Explain the rules clearly before playing games & 15 & $25 \%$ \\
Choose the suitable games to the contents of the lesson & 16 & $26.7 \%$ \\
Give them more chance to practice speaking English & 11 & $18.3 \%$ \\
Have a combination between games with music and picture & 10 & $16.7 \%$ \\
Give the gift or marks for example for the winners & 8 & $13.3 \%$ \\
\hline
\end{tabular}

\section{6) Question 6}

As presented in Table 6, when students were asked about the frequency of using games in vocabulary class, up to $41.6 \%$ of students expected that games should be used as many times as possible, and $21.7 \%$ of them wanted to learn with games every lesson. $21.7 \%$ students, on the contrary, just wanted to have games once a semester. $6.7 \%$ wanted games twice a month and $8.3 \%$ once a week. Up to $36.7 \%$ did not want to study with games very often. This correlated with Question 3 with 20\%, students did not favor games much. In theories, games are mostly recommended for young learners and the students in this study were university students and maybe games were not very suitable to all of them. Only a small number of students did not like games in the vocabulary class. Briefly, the result of the mentioned expectations was greatly persuasive.

Table 6: Students' expectation about the frequency of using games

\begin{tabular}{lcc}
\hline How often should the teacher apply games? & Frequency & Percentage \\
\hline Every lesson & 13 & $21.7 \%$ \\
Once a week & 5 & $8.3 \%$ \\
Twice a month & 4 & $6.7 \%$ \\
Once a semester & 13 & $21.7 \%$ \\
As many times as possible & 25 & $41.6 \%$ \\
\hline
\end{tabular}


In general, the majority of students wanted to learn vocabulary with games mainly because they had many chances to practice the newly learned vocabulary in various ways and used the vocabulary in real situation. They felt relaxed in studying and motivated, All meant that using games in teaching vocabulary could bring the positive and conditions for improving the vocabulary learning in class. All this consequently led to better studying results.

\section{TEST DATA ANALYSIS}

\section{The mid-term test}

The writer used the first semester scored as the pre-test of the study to have the whole view of the English competency of the two classes. Tables 7 and 8 show the scores that the two groups got for English in the beginning of second semester of the school year 2020: $16.7 \%$ students in the control group had 5->6 marks while $23.3 \%$ students of the experiment group's level of English might be better than of the control group before the experiment.

After four weeks, the researcher applied the games in teaching vocabulary to the experimental group (i.e., 4 units from Units 9-12), students would have a mid-term test about the vocabulary that they had learnt. The results of the mid-term test showed in the Table 8 below.

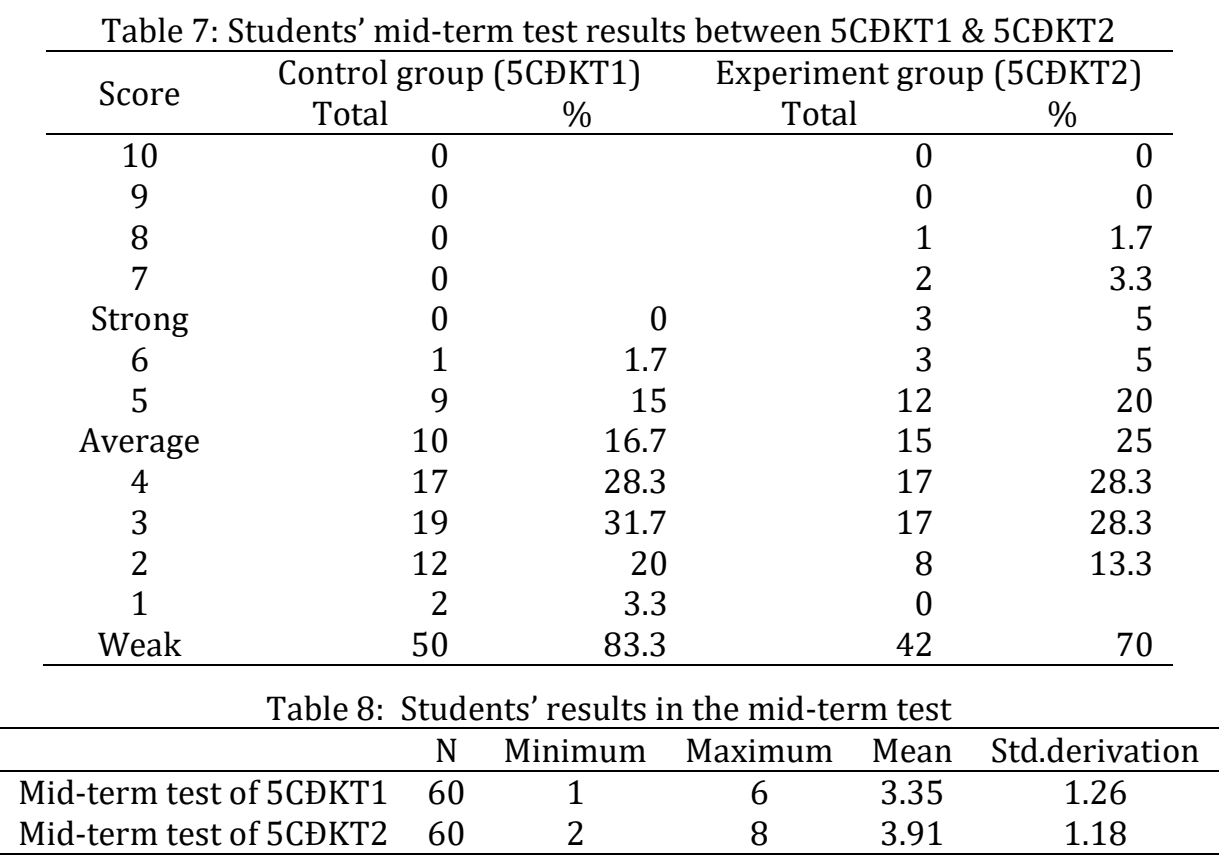

\section{The final test}

After eight weeks of the experimental teaching, a vocabulary test was carried out to check whether there was any academic improvement on the experimental group. The data was displayed in Table 9 below.

\begin{tabular}{|c|c|c|c|c|}
\hline \multirow{2}{*}{ Score } & \multicolumn{2}{|c|}{ Control group (5CĐKT1) } & \multicolumn{2}{|c|}{ Experimental group (5СĐКТ2) } \\
\hline & Total & $\%$ & Total & $\%$ \\
\hline 10 & 0 & 0 & 7 & 11.7 \\
\hline 9 & 1 & 1.7 & 20 & 33.3 \\
\hline 8 & 24 & 40 & 16 & 26.6 \\
\hline 7 & 20 & 33.3 & 9 & 15 \\
\hline Strong & 45 & 75 & 52 & 86.6 \\
\hline 6 & 12 & 20 & 4 & 6.7 \\
\hline 5 & 3 & 5 & 4 & 6.7 \\
\hline Average & 15 & 25 & 8 & 13.3 \\
\hline 4 & 0 & 0 & 0 & 0 \\
\hline 3 & 0 & 0 & 0 & 0 \\
\hline 2 & 0 & 0 & 0 & 0 \\
\hline 1 & 0 & 0 & 0 & 0 \\
\hline Weak & 0 & 0 & 0 & 0 \\
\hline
\end{tabular}

Comparison between the means of mid-term test and final test of the control and experiment groups was displayed in Tables 8 and 10. The mean of mid-term test and final test scores of the control group rose from 3.35 to 7.13 which reflected a large progress in their vocabulary competence, although students spent a lot of time (8 weeks) to learn 
vocabulary in the normal ways doing the exercises given in the textbook and had a little chance to practice the target language. Most of them could get the good results in the vocabulary test. Whereas the final test mean score of the experimental group showed a significant change from 3.91 to 8.08. The range of scores was also narrower; the lowest score was 5 and the highest was 10 . Learning vocabulary with games, their vocabulary competence of this group improved greatly after 8 weeks.

Table 10: Students' results in the final test

\begin{tabular}{lccccc}
\hline & $\mathrm{N}$ & Minimum & Maximum & Mean & Std.derivation \\
\hline Final test of 5CĐKT1 & 60 & 5 & 9 & 7.13 & 1.25 \\
Final test of 5CĐKT2 & 60 & 5 & 10 & 8.08 & 1.22 \\
\hline
\end{tabular}

In short, analyzing the means of scores of the mid-term test and the final test of both groups pointed out that though both groups made progress in their vocabulary learning. Now they had no weak students, only average and strong ones. In comparisons with the mid-term test, the control group now had $75 \%$ students with strong marks while in the mid-term test, they had none. Anyhow the test results of the experiment students were considered higher than that of the control group. The experiment group had $86.6 \%$ students with strong marks.

In sum, with the intervention of games, students' scores improved considerably. In other words, the vocabulary learning of Bac Lieu University non-English-majored students and contexts were improved positively together with their scores.

\section{CONCLUSION}

It is clearly said that using games to improve students' learning vocabulary was a teaching technique in which students were considered as the key element of the learning tasks. Using games to facilitate the learning acquisition in ways that students practiced, renewed, and extended their vocabulary stock, directly had impact on communication and developing meaningful learning. Besides, as shown from the study, cooperative vocabulary games also set up class cohesion, fostered the positive evaluation of all class members, and promoted healthy competition. The last but not least, using games created a good chance for students in practice the target language effectively. This study revealed the positive effects of applying games in improving students' learning vocabulary at Bac Lieu University. Students had positive learning conditions and thus they had better scores. Besides, teachers should be cautious not to rely all the activities on games as there was a small part of students did not feel very comfortable learning with games and games could be applied but not very often.

\section{REFERENCES}

Bahari, A. (2020). Game-based collaborative vocabulary learning in blended and distance L2 learning. Open Learning: The Journal of Open, Distance and e-Learning, 1-22.

Bartlett, J., Kotrlik, J., \& Higgins, C. (2001). Organizational research: Determining appropriate sample size in survey research. Information Technology, Learning, and Performance Journal, 19(1), 43-50.

Chen, H.-J. H., \& Yang, T.-Y. C. (2013). The impact of adventure video games on foreign language learning and the perceptions of learners. Interactive Learning Environments, 21(2), 129-141.

Chou, M. (2012). Assessing English vocabulary and enhancing young English as a Foreign Language (EFL) learners' motivation through games, songs, and stories. Education 3-13, 42(3), 284-297.

Creswell, J. W. (2012). Educational Research (4th ed.). Pearson Education.

Dehghanzadeh, H., Fardanesh, H., Hatami, J., Talaee, E., \& Noroozi, O. (2019). Using gamification to support learning English as a second language: a systematic review. Computer Assisted Language Learning, 1-24.

Ellis, R. (1997). SLA research and language teaching. Oxford: Oxford University Press.

Ebrahimzadeh, M., \& Alavi, S. (2016). Motivating EFL students: E-learning enjoyment as a predictor of vocabulary learning through digital video games. Cogent Education, 3(1), 1-14.

Harmer, J. (1993). The practice of English language teaching (New Ed). London: Longman.

Hwang, G. J., \& Wang, S. Y. (2016). Single loop or double loop learning: English vocabulary learning performance and behavior of students in situated computer games with different guiding strategies. Computers \& Education, 102(5), 188-201.

Lee, W. R. (1997). Language teaching games and contests. Oxford: Oxford University Press.

McCarthy, M. (1992). Vocabulary. Oxford: Oxford University Press.

Naber, T., \& Blackwell, A. (2005). English knowhow. Oxford: Oxford University Press.

Nunan, D. (1999). Second language teaching and learning. Heinle \& Heinle.

Obee, B. (1999). Games for young students. Cambridge: Cambridge University Press.

Rison, S. (1994). How to use games in language teaching. London: Macmillan Publishers Ltd.

Romp, G. (1997). Game theory: Introduction and applications. Oxford: Oxford University Press.

Thornbury, S. (2004). How to teach vocabulary. Essex: Pearson Education Limited.

Ur, P. (2009). Grammar practice activities: A practical guide for teachers. Cambridge: Cambridge University Press. 
Yip, F. W. M., \& Kwan, A. C. M. (2006). Online vocabulary games as a tool for teaching and learning English vocabulary. Educational Media International, 43(3), 233-249.

Zou, D., Huang, Y., \& Xie, H. (2019). Digital game-based vocabulary learning: where are we and where are we going? Computer Assisted Language Learning, 1-27.

Publisher's note: Science Impact Publishers remain neutral with regard to jurisdictional claims in published maps and institutional affiliations.

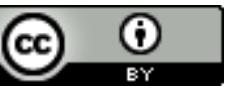

Open Access This article is licensed under a Creative Commons Attribution 4.0 International License, which permits use, sharing, adaptation, distribution and reproduction in any medium or format, as long as you give appropriate credit to the original author(s) and the source, provide a link to the Creative Commons license and indicate if changes were made. The images or other third-party material in this article are included in the article's Creative Commons license, unless indicated otherwise in a credit line to the material. If material is not included in the article's Creative Commons license and your intended use is not permitted by statutory regulation or exceeds the permitted use, you will need to obtain permission directly from the copyright holder. To view a copy of this license, visit https://creativecommons.org/licenses/by/4.0/.

(C) The Author(s) 2020 